\title{
From personal values to entrepreneurial intention: a systematic literature review
}

\section{Personal \\ values to \\ entrepreneurial \\ intention}

\author{
Juan Alberto Hueso and Inmaculada Jaén \\ Dept. Economia Aplicada I, University of Seville, Sevilla, Spain, and \\ Francisco Liñán \\ University of Seville, Sevilla, Spain and \\ School of Management, Anglia Ruskin University, Cambridge, UK
}

\begin{abstract}
Purpose - This systematic literature review (SLR) analyses the existing contributions, jointly studying personal values (PVs) and intentions in entrepreneurship. Despite the long tradition that these two constructs enjoy in social psychology, they have only recently been considered together in entrepreneurship research.

Design/methodology/approach - To conduct this SLR, three widely used databases were searched (Scopus, ABI-INFORM and Web of Science). A total of 451 initial hits were successively narrowed down to a final list of 22 journal articles matching the inclusion criteria. This field of research is very recent since the selected papers have all been published since 2011, half of which have appeared since 2017.

Findings - The predominant approach in these papers was the consideration of PVs as antecedents in the formation of entrepreneurial intentions (EIs). In particular, basic human values (BHV) theory for PVs and the theory of planned behaviour (TPB) for intentions are the prevalent frameworks. The influence of PVs differs notably depending on the motivational antecedent of intention being considered and also on the specific (general vs social) EI analysed.

Originality/value - This SLR is, to the best of the authors' knowledge, the first review that addresses this fast-growing area of research. It provides a comprehensive mapping of the contributions to date as well as an integrative conceptual framework to synthetise accumulated knowledge. It also identifies subsisting knowledge gaps and a number of future research opportunities.
\end{abstract}

Keywords Personal values, Entrepreneurial intention, Systematic literature review, Integrative framework Paper type Literature review

\section{Introduction}

For decades, entrepreneurship scholars have tried to increase their understanding of the entrepreneurial process (Galanakis and Giourka, 2017; Zahra et al., 2014). In particular, the entrepreneurial intention (EI) has attracted increasing attention as a key driver in predicting new venture creation behaviours (Bird, 1988; Kautonen et al., 2015). The theory of planned behaviour (TPB) is undoubtedly the most widely used model in EI research (Liñán and Fayolle, 2015; Schlaegel and Koenig, 2014).

Intentions are considered the single best predictor of behaviour (van Gelderen et al., 2018; Krueger and Carsrud, 1993). In this respect, intentions reflect the magnitude of the effort the individual is prepared to exert to perform a certain behaviour (Ajzen, 1991). Intention itself is the better established and the best empirically tested antecedent of entrepreneurial behaviour, according to the consolidated empirical (Delanoë-Gueguen and Liñán, 2019; Kautonen et al., 2015; Kautonen et al., 2013; Liñán and Rodríguez-Cohard, 2015; van Gelderen et al., 2018) and theoretical literature reviews (Fayolle and Liñán, 2014; Krueger, 2007; Krueger and Carsrud, 1993).

This manuscript has benefited from funding from the "ELITE: emergence of high-impact entrepreneurs" project (Spanish National R + D + I Plan, Ministry of Economics, Ref.: ECO2016-75655-P).

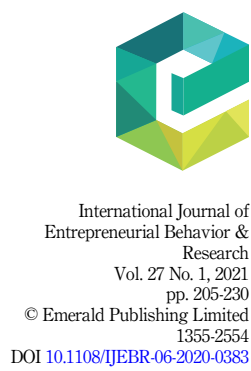


IJEBR

27,1

\section{6}

Research has striven to delve into the understanding of EI formation. For instance, several additional variables have been considered, such as the entrepreneurial identity (Pfeifer et al., 2016). Other authors, in turn, advocate the analysis of the role of personal values (PVs) in the entrepreneurial process (Fayolle et al., 2014). Related to this, certain studies have found that PVs play a key role in the entrepreneurial decision-making process. Thus, according to Gorgievski et al. (2011), the criteria to define success in entrepreneurial endeavours is related to prioritised PVs. Likewise, Bolzani and Foo (2018) associated the decision to internationalise with the PV system.

According to Veroff and Smith (1985), values are cognitive, deliberate and evaluative determinants of goals. Moreover, they establish the conception of the desirable (Kluckhohn, 1951). PVs represent the cognitive recognition of the correct way to behave or the correct end state to strive for (Rokeach, 1973). The importance of PVs lies in their capacity to guide goal setting and to act as the decision criteria in ambiguous or uncertain scenarios (Feather, 1995; Gorgievski et al., 2018). These PVs are important in explaining human actions (Bardi and Schwartz, 2003). They have been regarded as one of the most significant drivers in guiding intentions and subsequent behaviour (Maio et al., 2001; Murray et al., 1996).

The majority of research studies found that individualistic-like PVs (such as achievement, stimulation and self-direction) are those that exhibit a positive relationship with EIs (Liñán et al., 2016; Yang et al., 2015). In contrast, more recently, Hueso et al. (2020) found that collectivistic-like values are also related to EIs, although the relationship remains mostly indirect. Nevertheless, there are still relatively few studies analysing the relationship between PVs and EIs (Tipu and Ryan, 2016). Moreover, existing research is only partial and lacks an integrative perspective regarding this relationship. Therefore, the present research study aims to identify and analyse the extant literature on the role that PVs play in the formation of EIs. To this end, all articles published in academic journals up until the beginning of 2020 have been examined.

As a result of this literature review, a general overview of the accumulated knowledge on the relationship between PVs and EIs can be presented. This is important due to the role that PVs play in prompting decisions and actions (Feather, 1980, 1995), especially given the inherent complexity in entrepreneurial behaviour. Choosing to become an entrepreneur has far-reaching implications for the individual. Therefore, personal goals and priorities are likely to affect EIs through several mechanisms. The present research study identifies several of these mechanisms, although others still need to be addressed.

Additionally, the study proposes an integrative conceptual framework where the reviewed literature is synthetised, including potential relationships between PVs and other elements in the entrepreneurial process. Based on this framework, the manuscript identifies the specific knowledge gaps and proposes a future research agenda in this academic field. This study may therefore become a most relevant reference point for researchers in this field.

In the next section, the relevant theoretical framework is reviewed. The Research Methodology section then details how this literature review identifies the research work to be included. Section 4 describes the findings from our review. Section 5 discusses those results and considers their implications and is followed by a brief conclusion section.

\section{The theoretical framework}

Both the concept of PVs and that of intention originate from the literature on psychology. In particular, the work by Rokeach (1973) is considered to be one of the fundamental contributions to the theory of human values. Similarly, the work by Fishbein in collaboration with Ajzen (Fishbein and Ajzen, 1975) is also regarded as foundational in the study of behavioural intentions. However, there has been relatively little integration of both concepts within the entrepreneurship field of research. 


\section{Personal values}

The importance of PVs for each individual has long been recognised (Kluckhohn, 1951). Without a hierarchically organised system of PVs, individuals would not be able to make decisions and pursue their goals in life (Allport, 1961). Values should be given centrality as descriptive and explanatory concepts and, further, personality could be understood as a system of values (Rokeach, 1973). PVs are considered as guiding principles in life, where individual values remain relatively stable across situations and during human lifespan (Schwartz, 1992). Values are ordered by the relative importance that the individual attaches to each of them (Allport, 1961; Maslow, 1959; Pepper, 1958; Rokeach, 1973). The prevalence of certain values over others determines the individual's "dominating force" that conditions their day-to-day decisions (Allport, 1961, p. 543).

Values affect how people view situations, consider their alternatives and eventually act (Holland and Shepherd, 2013). These abstract structures, held as "organized summaries of experience", provide "continuity and meaning under changing environmental circumstances" (Feather, 1980, p. 249). However, definitional inconsistency remains epidemic in values theory and research (Rohan, 2000). The importance of people valuing priorities in understanding and predicting attitudinal and behavioural decisions has been emphasised (Rohan, 2000). The understanding of these PVs is important because they induce valences on possible actions (Feather, 1995). Therefore, the PV structure does indeed affect the individual perspective and how individuals make decisions and behave.

PVs guide individuals' intentions, choices and executed behaviours (Bardi and Schwartz, 2003). Values are about desirable end states or behaviours and transcend specific situations. As a consequence, they guide selection or evaluation of behaviour and events (Rokeach, 1973; Schwartz and Bilsky, 1987). Individuals behave according to their PV structure because they need a level of consistency between their beliefs and actions (Bardi and Schwartz, 2003; Rokeach, 1973). For this reason, PVs have been identified as a key factor in the decision-making process (Feather, 1980; Rokeach, 1973; Bardi and Schwartz, 2003).

Schwartz's (1992) theory of basic human values (BHV) is probably the most widely used framework to explain PVs. It identifies ten basic values that are prevalent in all individuals and these values form a quasi-circumplex structure based on the inherent conflict or compatibility between their motivational goals (Schwartz and Bilsky, 1987). Adjacent values are compatible, while opposing values are conflicting. The ten basic values may be grouped into four value dimensions (Schwartz, 1992): self-enhancement (including power and achievement values), openness to change (stimulation and self-direction values), selftranscendence (universalism and benevolence) and conservation (tradition, conformity and security). Hedonism would be placed between achievement and stimulation in the value circumplex and shares elements of the two corresponding value dimensions; for this reason, it is usually excluded when the value dimensions are studied (Gorgievski et al., 2018). According to this circumplex structure, self-enhancement and self-transcendence are opposing dimensions, as is openness to change and conservation.

\section{Entrepreneurial intention models}

The literature considers that intention models are central to ascertaining how individuals behave and develop their actions (Galanakis and Giourka, 2017). Therefore, a stronger intention to carry out this behaviour should reflect itself in a higher likelihood of it being performed (Ajzen, 1991). Behaviours are the consequence of affective (feeling and emotional responses), cognitive (beliefs, memories and perceptions of events) and conative variables (intentions and predictions about individual behaviour in response to an event) (Fishbein and Ajzen, 1975).
Personal

values to

entrepreneurial intention 
IJEBR

27,1

\section{8}

Entrepreneurship (or new venture creation) qualifies as a voluntary and conscious behaviour under volitional control (Bird, 1988; Krueger and Carsrud, 1993; Schlaegel and Koenig, 2014). Therefore, EIs are widely studied as a relevant antecedent for entrepreneurial behaviour (Delanoe-Gueguen and Liñán, 2019; Kautonen et al., 2015; van Gelderen et al., 2018). EIs are individual states of mind that direct attention, experience and actions towards the idea of starting up a new venture (Bird, 1988).

In entrepreneurship research, the TPB stands out as the most prominent model to explain the start-up intention (Krueger and Carsrud, 1993; Kautonen et al., 2013, 2015). In this model, the constructs explaining the individuals' EIs include the personal attitude (PA) towards entrepreneurship, subjective norms (SNs) and the perceived behavioural control (PBC). First, PA refers to the positive or negative evaluation or appraisal of the entrepreneurial behaviour and its consequences. Second, SNs symbolise the support expected from the individual's close environment (family, friends, relatives, etc.) if the individual exhibited start-up behaviours. Third, the $\mathrm{PBC}$ indicates the perceived ease or difficulty in undertaking entrepreneurial actions (Ajzen, 1991; Krueger and Carsrud, 1993; Kautonen et al., 2013, 2015).

The number of research studies into EIs is substantial (Liñán and Fayolle, 2015) and continues to grow (Donaldson, 2019). This research has identified a considerable amount of variables affecting the formation of intentions that include both personal and context variables (Liñán and Fayolle, 2015). In particular, PVs have been considered a motivational determinant of EIs (Fayolle et al., 2014).

\section{Personal values and entrepreneurial intentions}

Starting a venture is a complex process that involves the realisation of several tasks and usually includes considerable time delays (Galankis and Giourka, 2017; Kautonen et al., 2015). For this reason, it may be best described as a goal-directed behaviour (Bagozzi and Kimmel, 1995). Therefore, since PVs are the guiding principles that help both set and strive towards achieving personal goals (Rokeach, 1973; Schwartz, 1992), they should be relevant in the determination of EIs.

Despite this fact, few studies consider PVs as an antecedent of EIs (Liñán and Fayolle, 2015). Although research on the values of entrepreneurs remains relatively scarce (Holland and Shepherd, 2013), it indicates a significant relationship between individualist values and entrepreneurial behaviour (Liñán et al., 2016). Similarly, individualist values positively predict the EIs of respondents (Liñán et al., 2016; Yang et al., 2015). More recently, additional research has confirmed this relationship (Gorgievski et al., 2018; Morales et al., 2019).

Individualistic PVs, such as achievement, power and self-direction, are considered as being more consistent with entrepreneurship (Gorgievski et al., 2018) since they emphasise the pursuit of goals that may be achieved through this career choice. This influence may depend on the predominating cultural values in society and is thus affected by the context (Linán et al., 2016; Morales et al., 2019; Munir et al., 2019). On the other hand, research on the role of so-called collectivistic PVs on EIs is even scarcer. It finds support for the argument that certain collectivistic values could have a small indirect positive effect on EIs (Hueso et al., 2020). Therefore, there seems to be some conflict and substantial gaps in our knowledge regarding the PVs-EIs relationship. The literature review carried out in this paper may well contribute to shedding light on this relationship.

\section{The research methodology}

In order to perform this systematic review of the literature on PVs and EIs, the present research study follows previous methodological recommendations (Armitage and Keeble-Allen, 2008; Tranfield et al., 2003; Pittaway et al., 2014; Rauch, 2020). Literature 
reviews are most useful to systematise knowledge in any field since they serve to identify, evaluate and relate previous contributions in the research area (Mulrow, 1994). The distinct feature of a systematic literature review (SLR) is a well-established procedure that specifies the method employed to identify, select, assess and synthesise the evidence derived from previous publications (Armitage and Keeble-Allen, 2008; Boell and Cecez-Kecmanovic, 2015). It offers a normalised procedure to investigate the existing literature: a method that is replicable, transparent, objective, unbiased and rigorous (Boell and Cecez-Kecmanovic, 2015). This SLR is a domain-based review. It synthetises and extends a body of literature that resides in the same substantive domain (Palmatier et al., 2018).

The relevant search terms were selected in accordance with the aims of this study, as shown in Figure 1: personal* and value* and entrepreneur* and intent*. The search was carried out within the Scopus, ABI-INFORM and Web of Science databases. These three different databases were selected to make the search more comprehensive. The search terms were included in the following fields: article title, abstract and keywords. The time frame for the search was left open and unrestricted to any dates (the last search was carried out on 22nd March, 2020).

This search initially yielded 491 matches with 181 duplicates, which were immediately removed. The remaining 310 studies included 27 conference papers, six book chapters, four dissertations, seven non-academic journals and 27 non-English-language papers. All of these were excluded to avoid possible variability in the peer review process (Jones et al., 2011). The remaining 239 publications were content analysed to confirm their relevance. Publication dates ranged from 1992 (one paper) to 2001 (one paper) and showed a clear upward trend throughout the years up to 2019 (60 studies). The year 2020 (with five papers) remains incomplete. This is presented in Figure 2. Therefore, the studies jointly mentioning PVs and EIs are very recent and their production rate is also increasing very rapidly.

Each of these 239 papers was read by one of the authors to confirm its relevance according to our conceptual boundaries. First, 49 research papers were excluded. Despite the use of the key terms, they were not focussed on either EIs or PVs. A second realisation was that up to 103 papers were focussed on EIs, but they used the term "values" in a very loose manner not referring to PVs. These include papers on entrepreneurship education, which is generally argued should help instil "entrepreneurial values" in the participants and papers measuring

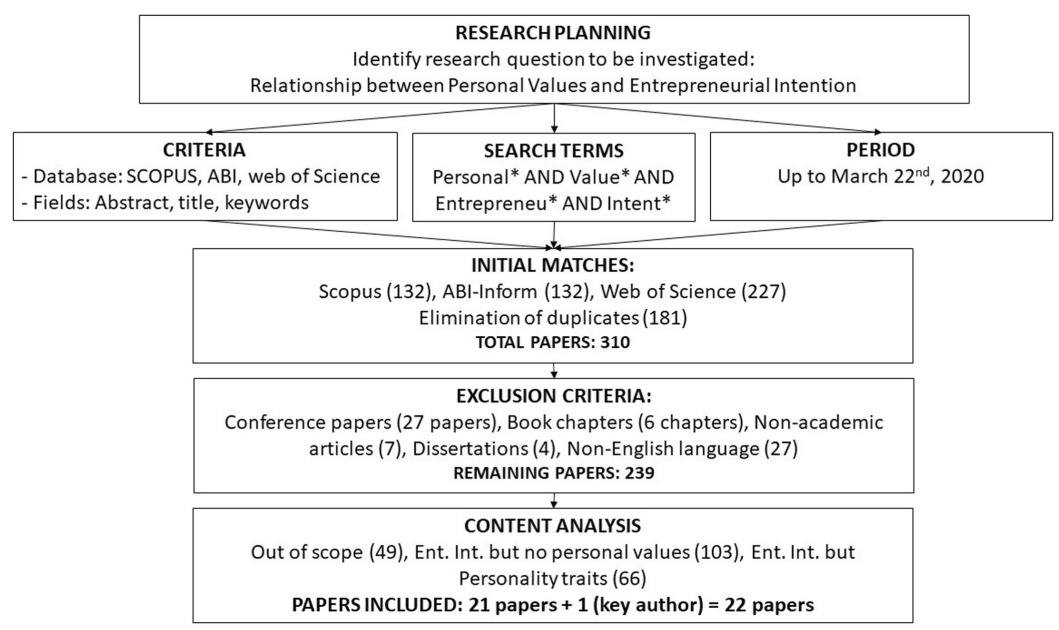

Figure 1.

Steps in the systematic literature review

entrepreneurial intention . 
IJEBR

27,1

\section{0}

attitudes through "expectancy value theory". In other words, the term "value" is used with the meaning of "valuable" or "worthy" or "characteristic" but not as personal goals or guiding principles (Schwartz, 1992). Several papers analysed "social values" as an indirect measure of culture or SNs, which again falls outside the scope of the study.

There are 66 other papers using the term "values" in the title, abstract or keywords but are effectively analysing "personality traits". Several of these papers analysed the Big Five personality traits (e.g. Nga and Shamuganathan, 2010) or other personality variables such as locus of control (e.g. de Pillis and Reardon, 2007), risk-taking propensity (e.g. Duffy et al., 2006), ability to identify opportunities (e.g. Pilková et al., 2017) and narcissism and Machiavellianism (e.g. Wu et al., 2019). Personality traits and PVs are both important in the configuration of the individual's mind. However, consolidated results from the psychology literature consider traits and values as distinct constructs (Olver and Mooradian, 2003). Traits are more biologically based (Goldberg, 1993; McCrae and Costa Jr, 2008), whereas values are a product of a person's environment, including culture, education, parental upbringing and life events (Rokeach, 1973). PVs reflect an individual's intentional goals and intentional commitments, while personality traits do not (Bilsky and Schwartz, 1994).

After the screening process, 21 documents were selected for inclusion. As a final check to guarantee comprehensiveness, additional relevant works from the key authors (authors of two or more of these 21 papers) were sought. One additional paper was thus found (Gorgievski et al., 2018), thereby yielding a total of 22 final papers included in the SLR. This additional paper was overlooked in the initial systematic search because it did not use the keyword "personal" in the search fields (instead, it used "human" and "individual").

\section{Findings}

Results are very recent, in general. The years of publication range from 2011 to 2020, half of which (11 papers) have appeared from 2017 onwards (see Figure 2). Thus, the initial findings are that the study of PVs and EIs is a very novel area of research and that the term "value" is used with very different meanings and not only as "personal guiding principles". In fact, it is only in 2011 that any papers using PVs in EI research are found at all.

\section{Synthesis of the results}

Summary information regarding the 22 articles matching the inclusion criteria is presented in Table A1. Most of the papers are empirical and employ quantitative techniques, except for one theoretical, two qualitative and one mixed-method (qualitative and quantitative) articles. The great majority of articles consider PVs as an antecedent that aids in the explanation of EIs. The only exceptions are the papers by Farrington et al. (2011) and by Geldhof et al. (2014).

Figure 2.

The time frame for the systematic literature review

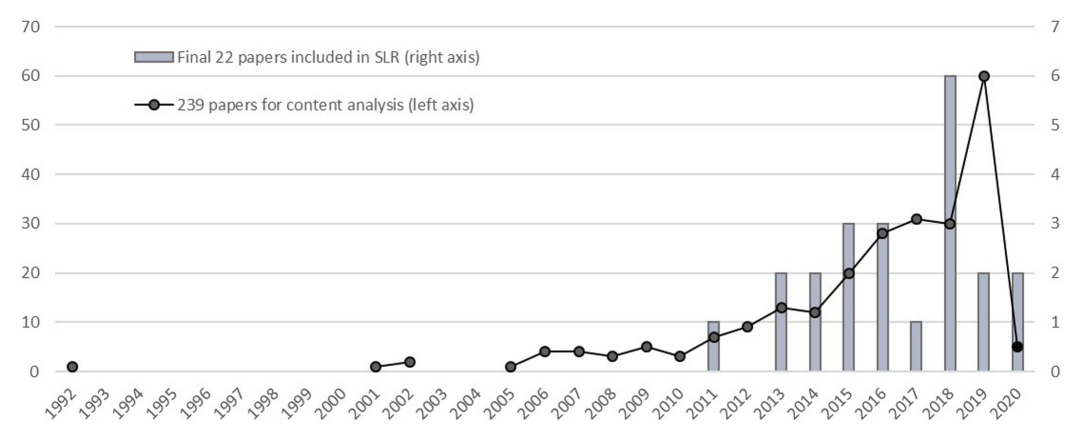


The former compares the work values associated with entrepreneurship in two different samples (business students and actual business owners) and finds that students exhibit values of a more idealistic nature than in the case of firm owners. In turn, Geldhof et al. (2014) used both PVs and EIs as predictors of entrepreneurial behaviours and their results indicate that entrepreneurial career values can predict innovation-related behaviours. Since the objective of this research is the analysis of papers jointly studying PVs and EIs, these two articles were maintained. They also provided some insight for the development of an integrative conceptual framework (see subsection below).

The remaining 20 papers consider PVs as direct or indirect antecedents of EIs. Here, a theoretical paper is included (Fayolle et al., 2014), which not only proposes this to be the case but also argues that PVs may moderate the intention-action link. Furthermore, two other papers propose and test PVs as direct antecedents of the entrepreneurial attitude (Sihombing, 2018; Yang et al., 2015), but they do so within a framework in which attitudes explain the intention to start up (Yang et al., 2015) or the intention to quit (Sihombing, 2018). Finally, there are two qualitative papers that analyse the goals motivating entrepreneurial decisions: either internationalisation (Bolzani and Foo, 2018) or starting up (Muhammad et al., 2019). The former considers PVs (as defined by Schwartz, 1992) as the more abstract values that motivate the internationalisation decision. The latter, in turn, uses no specific framework for PVs, but the values elicited are very close to some of Schwartz's (1992) values.

As shown in Table 1, the majority of papers (15) focus on the intention either to start up a commercial venture or to become an entrepreneur in general. In turn, there are four studies specifically focussing on the social entrepreneurial intention (SEI). Finally, there are three papers that centre on the intention to perform other entrepreneurial behaviours. They include the internationalisation intention (Bolzani and Foo, 2018), the green EI (Ye et al., 2020) and the intention to quit (Sihombing, 2018). These papers analysing alternative intentions are all very recent, which indicates that the study of PVs is expanding, not only in quantity (number of studies) but also in scope.

Similarly, the theoretical approach used in each paper to define PVs differs notably (see Table 2). Overall, there are six papers focussing on work values, of which Farrington et al. (2011) and Geldhof et al. (2014), as mentioned above, jointly analyse PVs and EIs to explain behaviour. Also, three of these papers focus on the relationship with general start-up

\begin{tabular}{|c|c|c|c|}
\hline $\begin{array}{l}\text { Personal } \\
\text { values } \\
\text { theory }\end{array}$ & Type of entrepren & $\begin{array}{l}\text { urial intention } \\
\text { Social entrepreneurial } \\
\text { Intention }\end{array}$ & $\begin{array}{l}\text { Other } \\
\text { intention }\end{array}$ \\
\hline $\begin{array}{l}\text { Basic human } \\
\text { values }\end{array}$ & $\begin{array}{l}\text { Fayolle et al. (2014), Espiritu-Olmos and Sastre- } \\
\text { Castillo (2015), Yang et al. (2015), Liñán et al. } \\
\text { (2016), Schmidt and Tatarko (2016), Fernandes } \\
\text { et al. (2018), Gorgievski et al. (2018), Hueso et al. } \\
\text { (2020) }\end{array}$ & $\begin{array}{l}\text { Sastre-Castillo et al. } \\
\text { (2015), Kruse et al. (2019) }\end{array}$ & $\begin{array}{l}\text { Bolzani and } \\
\text { Foo (2018) }\end{array}$ \\
\hline Work values & $\begin{array}{l}\text { Farrington et al. (2011), Hirschi and Fischer } \\
(2013)^{\mathrm{a}} \text {, Geldhof et al. (2014), Tipu and Ryan } \\
\text { (2016), Lechner } \text { et al. }(2018)^{\mathrm{a}}\end{array}$ & Kunttu et al. $(2017)^{\mathrm{b}}$ & \\
\hline Rokeach & & & $\begin{array}{l}\text { Sihombing } \\
(2018)\end{array}$ \\
\hline Other PVs & $\begin{array}{l}\text { Watchravesringkan et al. (2013), Muhammad } \\
\text { et al. (2019) }\end{array}$ & Bacq and Alt (2018) & Ye et al. (2020) \\
\hline
\end{tabular}

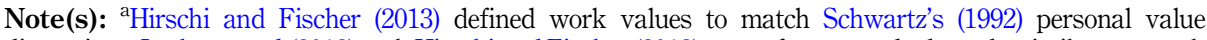
dimensions. Lechner et al. (2018) took Hirschi and Fischer (2013) as a reference and adopted a similar approach ${ }^{b}$ Kunttu et al. (2017) compared social entrepreneurial intentions with traditional start-up intentions
Personal values to entrepreneurial intention 
IJEBR

27,1

212

intentions. Amongst these three, Hirschi and Fischer (2013) specifically merge the concept of work values with PVs to analyse the effect on EIs. Similarly, Lechner et al. (2018) also defined work values as a reflection of PVs, with explicit reference to Schwartz's (1992) framework and to Hirschi and Fischer's (2013) paper. In both cases, significant gender differences are found. In contrast, Tipu and Ryan (2016) explored how work ethics affect the individuals' EIs. The sixth paper (Kunttu et al., 2017) compares the effect of work values on socially oriented EIs and goals, relative to traditional EIs. They find altruism to be positively related to SEI (but not to EI), while EI is related to security (negatively) and to intrinsic reward (positively).

Additionally, there are other approaches to measure PVs which are not specifically termed as work values but remain relatively close. This is the case of self-actualisation and social affiliation values (Watchravesringkan et al., 2013), empathy (Bacq and Alt, 2018), reasons/ motives to start up (Muhammad et al., 2019) and altruistic values (Ye et al., 2020). Sihombing (2018), in turn, adopted Rokeach's (1973) approach to measure PVs. She observed that instrumental values are not relevant in predicting the entrepreneurial attitude, whereas terminal values are positively related to this attitude. Finally, the remaining 11 papers used BHV theory (Schwartz, 1992) to conceptualise PVs, which renders this theory as the most common framework (more detailed results are given below).

Regarding the specific EI model, ten papers explicitly adopted Ajzen's (1991) TPB, which is by far the most common framework for EIs. Only one of these papers focusses on the SEI (Kruse et al., 2019), while the remaining nine papers use the TPB to analyse the general intention to start up a new business. The theoretical contribution by Fayolle et al. (2014) has been included here, together with one of the qualitative papers (Muhammad et al., 2019). The remaining papers adopting a TPB framework carry out a quantitative empirical analysis. In particular, there are five quantitative papers integrating Schwartz's (1992) BHV and Ajzen's (1991) TPB to measure general start-up intentions (Gorgievski et al., 2018; Hueso et al., 2020; Liñán et al., 2016; Schmidt and Tatarko, 2016; Yang et al., 2015) as discussed in greater detail in the following subsection.

Other papers adopt very different approaches to model EIs. In fact, a number of papers use an eclectic approach to define this variable. They combine contributions from different frameworks to develop the hypotheses regarding the effect of PVs and other variables on EIs. This is the case of seven papers: Hirschi and Fischer (2013), Espiritu-Olmos and SastreCastillo (2015), Sastre-Castillo et al. (2015), Tipu and Ryan (2016), Kunttu et al. (2017), Fernandes et al. (2018) and Lechner et al. (2018). Geldhof et al. (2014) also use an eclectic framework to define EIs but in this case, this variable is employed to predict behaviours.

Finally, there are four papers adopting other less commonly used approaches to define and model EIs. Bacq and Alt (2018) employed a combined model of SEI (Mair and Noboa, 2006) to analyse the influence of empathy on this variable. Bolzani and Foo (2018) adopted a laddering theory (Reynolds and Gutman, 1988) to predict the internationalisation intention and uncover five of Schwartz's basic values at the base of the internationalisation intention. Sihombing (2018) followed the value-attitude-behaviour hierarchy as defined by Homer and Kahle (1988) with a focus on the intention to quit as an entrepreneur. Finally, Ye et al. (2020) used the push-pull-mooring model (Moon, 1995) to predict the intention to switch to green entrepreneurship.

\section{The integrative conceptual framework}

Despite the considerable complexity and variability in the approaches found within these 22 papers, certain overarching patterns emerge that enable an integrative conceptual framework to be developed. The overwhelming majority of papers consider PVs as an antecedent of EIs that are either directly connected or mediated by other variables (e.g. Gorgievski et al., 2018; Hueso et al., 2020). Nevertheless, there are two contributions in which 
EIs and PVs are considered as independent variables jointly affecting actual behaviour (Farrington et al., 2011; Geldhof et al.,2014). This is in line with the possible mediating effect of PVs on the intention-behaviour relationship, as suggested by Fayolle et al. (2014).

Given that the TPB (Ajzen, 1991) and BHV (Schwartz, 1992) are the most commonly applied theories, and that their joint use is found in nearly one-third of the papers (seven out of 22 , six empirical and one theoretical), it seems appropriate to base the integrative framework thereon. In this respect, the first reflection is that PVs are considered as distant predictors of intention through the mediation of motivational antecedents. Nevertheless, a number of papers test the direct relationship between PVs and EIs. Liñan et al. (2016) is one of them using the BHV-TPB framework. Figure 3 presents the integrative conceptual framework. Solid lines indicate relationships that have been analysed in these 22 papers, while dotted lines represent relationships yet to be tested. In particular, as Fayolle et al. (2014) suggested, PVs may moderate the intention-action link. Similarly, Delanoë-Gueguen and Liñán (2019) found the security work motivation (very close to the PV of security) to moderate this relationship and also to exert an independent and direct negative effect on start-up behaviour.

The influence of each value dimension on the TPB variables has been independently analysed in these papers and consistent results were found. They are not presented in Figure 3 for reasons of clarity but are instead summarised in Table 2 based on the six empirical papers that test the BHV-TPB approach. Also, five of these papers propose and test a partial or total mediation model (Gorgievski et al., 2018; Hueso et al., 2020; Kruse et al., 2019; Schmidt and Tatarko, 2016; Yang et al., 2015) and this is also the relationship proposed in the theoretical paper (Fayolle et al., 2014). The main results are described below, organised in terms of PV dimensions.

Within the self-enhancement value dimension (achievement and power values), the results for Liñán et al. (2016) indicated a direct positive relationship with EIs, even after controlling for the TPB antecedents. Yang et al. (2015), in turn, noted mixed results for the indirect effect of these values through the entrepreneurial PA. Gorgievski et al. (2018) observed that selfenhancement values positively predict self-efficacy (a proxy for PBC), while they negatively affect SNs. In the case of SEIs, Kruse et al. (2019) pointed not only towards a positive indirect relationship between these values and the SEI through both PA and PBC but also towards a negative direct relationship, whose direct and indirect effects cancel each other out. Related to

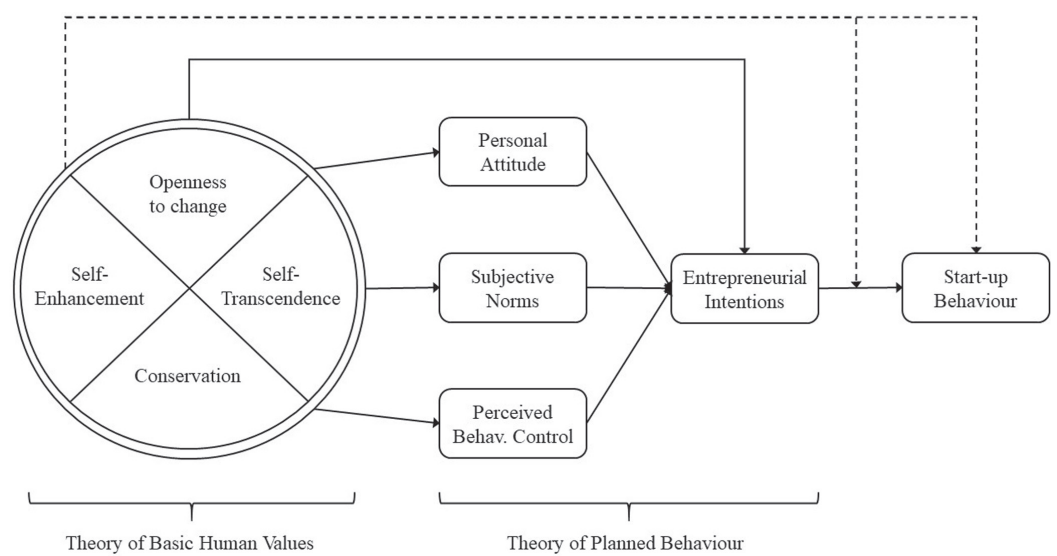

Note(s): Solid lines represent relationships tested in the papers analysed.

Dotted lines represent relationships yet to be tested
Personal values to entrepreneurial intention
Figure 3.

The integrative conceptual framework 
IJEBR

27,1

\section{4}

this, although without applying the joint BHV-TPB framework, Bolzani and Foo (2018) found both self-enhancement values at the basis of the internationalisation decision. Similarly, Espiritu-Olmos and Sastre-Castillo (2015) also remarked that self-enhancement positively relates to EIs; Sastre-Castillo et al. (2015) agreed and also found it to be negatively related to a social orientation. Finally, both Hirschi and Fischer (2013) and Lechner et al. (2018) observed a positive relationship between self-enhancement-related work values and EIs.

In the case of openness to change values (self-direction and stimulation), the results are much clearer. Schmidt and Tatarko (2016) found a positive relationship between selfdirection and all three motivational antecedents of EIs. Gorgievski et al. (2018) replicated this finding for PA and PBC. Yang et al. (2015) confirmed this result for the PA antecedent, while Liñán et al. (2016) corroborated a positive direct relationship between these values and EIs. In the case of SEIs, Kruse et al. (2019) also noted that this value dimension relates positively and significantly to PA, PBC and to SEIs directly. Additional support for this relationship may be found in those papers that do not combine TPB and BHV theories. In this way, Sastre-Castillo et al. (2015) observed a direct positive relationship with EIs but not with the social orientation. Bolzani and Foo (2018) also remarked self-direction to be at the basis of the internationalisation decision. Again, Hirschi and Fischer (2013) and Lechner et al. (2018) reported a positive relationship between variety and autonomy work values (matching the openness to change dimension) and EIs.

The remaining value dimensions (self-transcendence and conservation) are more strongly associated with collectivistic values. In this respect, Yang et al. (2015) reported a negative relationship of all the values in these dimensions (except for universalism) with the entrepreneurial PA. Similarly, Schmidt and Tatarko (2016) observed security (a conservation value) to negatively affect the PA. In turn, Hueso et al. (2020) reported a more complex relationship, where all these values have a negative relationship with PA and PBC (although not always significant), while they all have a positive relationship with SNs (again, not always significant). Other papers (not combining TPB and BHV theories) found certain conflicting results since conservation values are found to have a direct positive relationship with EIs (Fernandes et al., 2018). Bolzani and Foo (2018) noted security and benevolence values to be at the basis of the intention to internationalise. Finally, Hirschi and Fischer (2013) reported that security and authority work values (matching the conservation dimension) negatively relate to EIs, while Lechner et al. (2018) observed security and social/interpersonal work values (close to the conservation and self-transcendence dimensions, respectively) to be associated with a lower EI.

Table 2.

The influence of basic human values dimensions on the theory of planned behaviour variables

\begin{tabular}{|c|c|c|c|c|}
\hline $\begin{array}{l}\text { Personal value } \\
\text { dimensions }\end{array}$ & $\begin{array}{l}\text { Attitude to } \\
\text { entrepreneurship }\end{array}$ & $\begin{array}{l}\text { TPB antecedents } \\
\text { Subjective } \\
\text { norms }\end{array}$ & $\begin{array}{l}\text { Perceived } \\
\text { behavioural control }\end{array}$ & $\begin{array}{l}\text { Entrepreneurial } \\
\text { intention }\end{array}$ \\
\hline Self-enhancement & $\begin{array}{l} \pm(\mathrm{EI}) \\
+(\mathrm{SEI})\end{array}$ & $-(\mathrm{EI})$ & + (EI, SEI) & $\begin{array}{l}+(\mathrm{EI}) \\
-(\mathrm{SEI})\end{array}$ \\
\hline Openness to change & + (EI, SEI) & $+(\mathrm{EI})$ & $+(\mathrm{EI}, \mathrm{SEI})$ & + (EI, SEI) \\
\hline Self-transcendence & $\begin{array}{l} \pm(\mathrm{EI}) \\
+(\mathrm{SEI})\end{array}$ & $+(\mathrm{EI})$ & $\begin{array}{l}-(\mathrm{EI}) \\
+(\mathrm{SEI})\end{array}$ & $+(\mathrm{SEI})$ \\
\hline Conservation & $-(\mathrm{EI})$ & $+(\mathrm{EI})$ & $-(\mathrm{EI})$ & - (SEI) \\
\hline
\end{tabular}

Note(s): Based on the results from Gorgievski et al. (2018), Hueso et al. (2020), Kruse et al. (2019), Liñán et al. (2016), Schmidt and Tatarko (2016) and Yang et al. (2015)

$+=$ positive relationship; $-=$ negative relationship; $\pm=$ conflicting results. $\mathrm{EI}=$ general entrepreneurial intention; SEI: social entrepreneurial intention 
It should be borne in mind that different results are found when the SEI is considered. In this case, Kruse et al. (2019) found self-transcendence to be positively related both to the antecedents of intention (PA and $\mathrm{PBC}$ ) and also directly to the SEI itself. Conservation, in contrast, is not related to the antecedents and has a negative influence on the SEI. This is supported by other research studies based on alternative theoretical models. Thus, Kunttu et al. (2017) noted altruism (close to self-transcendence values) to be positively related to SEIs. Bacq and Alt (2018) reported a similar positive result for empathy. In turn, the results from Sastre-Castillo et al. (2015) supported a positive relationship between self-transcendence and conservation values and a social entrepreneurial orientation.

\section{Discussion}

This SLR has identified 22 articles that jointly examine the role of PVs and EIs in entrepreneurship. Although this is a recent area of research (all papers are from 2011 or later), it is growing rapidly. The review is timely, in that it offers a comprehensive panoramic view of the accumulated knowledge to date and develops an integrative conceptual framework. A first conclusion to be drawn is that research to date overwhelmingly considers PVs as an antecedent in the formation of EIs, in accordance with the conceptualisation of PVs as basic guiding principles in life (Rokeach, 1973; Schwartz, 1992). Thus, they should be expected to play a role in making decisions regarding desirable and/or feasible courses of action (one of which being entrepreneurship).

BHV-TPB is the most frequent combination of theories used. There are practically no alternative theoretical formulations that may compete in this respect. In the case of PVs, up to six papers analyse work values but with no common underlying framework. In fact, two of these papers (Hirschi and Fischer, 2013; Lechner et al., 2018) base their work values on Schwartz's (1992) BHV theory. The results from the BHV-TPB-based research study tend to be consistent, with few exceptions. Only in the case of the relationship between selftranscendence and self-enhancement values and PA does there seem to be clear conflict. Yang et al. (2015) found opposing relationships for each of the basic values in these dimensions. In turn, Hueso et al. (2020) observed a negative relationship between universalism and PA. There may be cultural elements underlying these differences. Previous research has shown that shared cultural values affect the individual's intention-formation process (Jaén and Liñán, 2013; Liñán et al., 2016; Munir et al., 2019).

Another major source of difference is the specific intention under analysis. Kunttu et al. (2017) explicitly compared SEIs and (general) EIs. They remarked that the work values predicting each of these intentions do indeed differ. Similarly, Kruse et al. (2019) used BHV and TPB to explain the formation of SEI. Their results were most insightful when compared to similar models for general EIs (Gorgievski et al., 2018; Hueso et al., 2020; Schmidt and Tatarko, 2016; Yang et al., 2015), (see Table 2). For several relationships, the effect of PVs on the TPB variables appears to be consistent (e.g. openness-to-change values affecting any TPB variable), while for others a conflict is found (e.g. the influence of self-transcendence on $\mathrm{PBC})$.

\section{Implications and future research opportunities}

Several implications for academic research may be derived from this SLR. As a relatively new area of research, there are substantial knowledge gaps yet to be filled. The papers reviewed here provide a basic framework from which new research lines may be identified. The most relevant research questions emerging from this review are summarised in Table 3. However, this is not to be taken as an exhaustive list since many additional questions may be posed.

With few exceptions (Fernandes et al., 2018; Yang et al., 2018), research tends to group the basic human values into four value dimensions. This may increase consistency and reliability 


\section{IJEBR 27,1}

\section{6}

Knowledge gaps

Value dimensions vs basic human values

Single dimensions vs complete value circumplex

Effects on different types of intentions

Theoretical frameworks

Different samples

Context characteristics

PVs in entrepreneurship education

Table 3.

Knowledge gaps and future research opportunities
Research opportunities

(1) Role of individual values

(2) Specific combinations of basic values

(1) Role of individual dimensions

(2) Combinations of two adjacent dimensions

(3) Combinations of opposing dimensions

(4) Cancelling out effects

(5) Direct and indirect effects of value dimensions

(1) SEIs vs general EIs

(2) Sustainable EIs

(3) Small life style venture vs scalable start-up

(4) High-technology vs traditional craft venture

(5) Intention to internationalise, to grow, to innovate or to quit

(1) TPB vs competing intention models (e.g. entrepreneurial event model, social cognitive career theory)

(2) BHV vs alternative value theories (e.g. work values)

(1) Representativeness of student samples

(2) Young vs older adults

(3) Natives vs immigrants

(1) Cultural values

(2) Life stages

(3) Family or personal circumstances

(1) Malleability of PVs

(2) Design of education interventions to affect PVs

(3) Evaluation of entrepreneurship education

(4) PVs and learning

(5) PVs and entrepreneurial identity

of the results but possibly at the expense of losing detailed relationships. Are certain individual basic values relevant in themselves to explain EIs and subsequently behaviour? Or are there specific combinations of basic values that are more promising in this respect? In particular, hedonism (seeking satisfaction and pleasure) is frequently ignored (since it is not included in the four value dimensions). Neither Fernandes et al. (2018) nor Yang et al. (2018) found any effect of hedonism on intentions. Nevertheless, the combination of hedonism with additional basic values might be relevant.

The same reflections may apply to the four value dimensions. Is a high level of openness to change sufficient to develop the EI? Or is this the case for self-enhancement? Or are high levels of both individualistic-like dimensions necessary? Much research is needed to fully understand the roles of each dimension in explaining the development of EIs and action. Adjacent dimensions may reinforce each other, as could be the case of openness to change and self-enhancement for general EIs (Liñán et al., 2016) or of openness to change and selftranscendence for social EIs (Kruse et al., 2019). Additionally, opposing dimensions may cancel each other out and hence, a high level of one dimension may be insufficient if the opposing dimension is also prioritised. The indirect effects of value dimensions on EI, through the TPB antecedents, also deserve attention. Hueso et al. (2020) and Gorgievski et al. (2018) found certain dimensions to affect one antecedent positively and another negatively. Predicting the aggregate effect of these dimensions on EIs would be complex, and even if no such total effect is found, this does not necessarily mean that the value dimensions are irrelevant.

The intention to start up a (general) venture is by far the most common intention analysed, with the TPB (Ajzen, 1991) as the predominant theoretical framework. Nevertheless, several 
papers considered alternative intentions, such as social entrepreneurship (Bacq and Alt, 2018; Kruse et al., 2019; Kunttu et al., 2017; Sastre-Castillo et al., 2015), internationalisation (Bolzani and Foo, 2018), green entrepreneurship (Ye et al., 2020) and quitting (Sihombing, 2018) intentions. In this respect, Table 2, which compares SEI vs EI, is based on only a few studies. There are still several relationships for which no comparison is yet available. Much more work is needed to confirm or refute these results. Additionally, the role of PVs may differ depending on which specific intention (to perform a certain behaviour) is under consideration. Therefore, the potential entrepreneur's PV structure may have substantial implications for the type of venture being created and its future evolution.

The use of alternative theoretical frameworks should also be explored. A number of competing intention models exist, such as the entrepreneurial event model. However, Schlaegel and Koenig (2014) found a substantial overlap between this model and the TPB. Another interesting avenue for further research could involve other such theories. Nevertheless, this research should be able to demonstrate an improvement over the TPB in order to be of any value. In the case of PVs, BHV is the most commonly used framework for their conceptualisation, either directly or indirectly (Hirschi and Fischer, 2013; Lechner et al., 2018). Work values, in turn, have been defined differently in several of these papers (e.g. Farrington et al., 2011; Geldhof et al., 2014; Tipu and Ryan, 2016). There seems to be much less consensus concerning the most suitable approach for the identification of work values that affect entrepreneurship.

The vast majority of the papers analysed use student samples. There is considerable debate regarding the representativeness of these samples. The comparison of these results with those from comparable studies with alternative samples of adults is therefore of major interest. Additionally, the priorities of an individual's PVs are likely to evolve as they advance through their different life stages (Schwartz, 1992). Thus, the role of PVs in the formation of EIs may differ in younger vs older people. Similarly, immigrants tend to exhibit higher startup rates than is the case for natives. This may be a consequence of differing cultural values which, to a great extent, are reflected in prioritised PVs.

The role of cultural values is also relevant. Liñán et al. (2016) argued that the influence of $\mathrm{PVs}$ on intention is stronger for individuals who prioritise different values from those in the society where they live. This could explain why immigrants are more prone to starting up new businesses and why in multicultural societies, certain ethnic groups are more entrepreneurial than others. Do individuals with different priorities respond differently to the same situation? And do individuals with the same priorities respond differently due to their different situations (such as dependence on family circumstances)?

PVs remain relatively stable over time (Bardi et al., 2009). Therefore, the relevance of understanding their influence may be questioned. However, research has found that these values may be modified, for example, via education (Myyry et al., 2013). This may happen through purposeful actions taken by teachers, but may also take place unintentionally through peer interaction and similar socialisation practices (Racko et al., 2017). There is, therefore, an obvious opportunity to develop and implement entrepreneurship education initiatives that include specific value-transmitting and value-changing components. Training activities, therefore, may be devised to contribute towards modifying the value structure of the participants. Future research could help not only in the search for the most promising combination of values to promote entry into entrepreneurship but also to foster responsible and sustainable behaviour as an entrepreneur. The evaluation of education initiatives in this respect should be a long-term exercise. Longitudinal studies are called for to achieve this aim. Hitherto, they have been the exception: only one of the 22 papers analysed here carries out a longitudinal study (Lechner et al., 2018).

The PV structure may stimulate learning and skill development in value-congruent domains (Caprara and Steca, 2007). This could help explain why certain individuals exhibit
Personal values to entrepreneurial intention 
IJEBR

27,1

\section{8}

higher entrepreneurial self-efficacy, once experience and other background variables are controlled for. Similarly, PVs could also influence the recognition of business opportunities (Shepherd et al., 2013) or the entrepreneurs' choices for the firm's strategic priorities (Gorgievski et al., 2011). Entrepreneurial identity is also likely to be related to PVs. In this regard, the concept of "authenticity" has been linked to individuals behaving in accordance with their values (Gecas and Burke, 1995). Thus, PVs could reflect an activation of one's own personal identity (Hitlin, 2003). Therefore, specific combinations of PVs could promote the formation of an entrepreneurial identity. There is an obvious gap to be filled by testing the model by using similar sample characteristics, the operationalisation of measures and by controlling either for other variables in the model or for contextual factors.

\section{Conclusions}

This is the first systematic review of the literature which, to the best of our knowledge, jointly analyses PVs and EIs. Judging by the publication dates, this is a rapidly growing area of research. The present study will be useful for other researchers entering into this area of analysis since it provides not only a comprehensive mapping of the theories and methods used to date but also the results that they report. Furthermore, this review provides an integrative conceptual framework to synthetise knowledge to date and identifies a number of knowledge gaps and opportunities that remain open for future research.

Despite being a very recent field of research, it is already opening up into several different streams. The core of the field is the consideration of PVs (typically conceptualised under BHV theory) as antecedents in the formation of EIs (most often considered from the perspective of the TPB). Alternative lines of analysis, however, have already been found. In particular, alternative entrepreneurship-related intentions are being considered, with SEIs as the most frequent. Evidence has already been provided that PVs differ in their effect on the formation of either social or general EIs.

Finally, this study, as for any literature review, is not without its limitations. First, certain relevant contributions may not have been analysed. This may have happened either because they were not initially detected (our keywords may not have been sufficiently comprehensive) or because they have been inadequately excluded. Nevertheless, the authors have been as systematic and rigorous as possible to prevent this from happening. Second, there is always an element of subjectivity in the classification of papers, despite every precaution taken. For this reason, all doubts were discussed amongst all the authors before any decision was made. Despite any limitations, researchers in the field will find this contribution to be relevant and helpful.

\section{References}

Ajzen, I. (1991), "The theory of planned behavior", Organizational Behavior and Human Decision Processes, Vol. 50 No. 2, pp. 179-211.

Allport, G.W. (1961), Pattern and Growth in Personality, Holt, Reinhart and Winston, New York, NY.

Armitage, A. and Keeble-Allen, D. (2008), "Undertaking a structured literature review or structuring a literature review: tales from the field", Journal of Business Research Methods, Vol. 6 No. 2, pp. 103-114.

Bacq, S. and Alt, E. (2018), "Feeling capable and valued: a prosocial perspective on the link between empathy and social entrepreneurial intentions", Journal of Business Venturing, Vol. 33 No. 3, pp. 333-350.

Bagozzi, R.P. and Kimmel, S.K. (1995), "A comparison of leading theories for the prediction of goaldirected behaviours", British Journal of Social Psychology, Vol. 34 No. 4, pp. 437-461. 
Bardi, A. and Schwartz, S.H. (2003), "Values and behavior: strength and structure of relations", Personality and Social Psychology Bulletin, Vol. 29 No. 10, pp. 1207-1220.

Bardi, A., Lee, J.A., Hofmann-Towfigh, N. and Soutar, G. (2009), "The structure of intraindividual value change", Journal of Personality and Social Psychology, Vol. 97 No. 5, pp. 913-929.

Bilsky, W. and Schwartz, S.H. (1994), "Values and personality", European Journal of Personality, Vol. 8 No. 3, pp. 163-181.

Bird, B. (1988), "Implementing entrepreneurial ideas: the case for intention", Academy of Management Review, Vol. 13 No. 3, pp. 442-453.

Boell, S.K. and Cecez-Kecmanovic, D. (2015), “On being 'systematic' in literature reviews”, in Formulating Research Methods for Information Systems, Palgrave Macmillan, London, pp. $48-78$.

Bolzani, D. and Foo, M. (2018), "The "why" of international entrepreneurship: uncovering entrepreneurs' personal values", Small Business Economics, Vol. 51 No. 3, pp. 639-666.

Caprara, G.V. and Steca, P. (2007), "Prosocial agency: the contribution of values and self-efficacy beliefs to prosocial behavior across ages", Journal of Social and Clinical Psychology, Vol. 26 No. 2, pp. 218-239.

Cennamo, L. and Gardner, D. (2008), "Generational differences in work values, outcomes and personorganisation values fit", Journal of Managerial Psychology, Vol. 23 No. 8, pp. 891-906.

de Pillis, E. and Reardon, K.K. (2007), "The influence of personality traits and persuasive messages on entrepreneurial intention”, Career Development International, Vol. 12 No. 4, pp. 382-396.

Delanoë-Gueguen, S. and Liñán, F. (2019), "A longitudinal analysis of the influence of career motivations on entrepreneurial intention and action", Canadian Journal of Administrative Sciences/Revue Canadiennedes Sciences de l'Administration, Vol. 36 No. 4, pp. 527-543.

Diefendorff, J.M. and Chandler, M.M. (2011), "APA handbook of industrial and organizational psychology: maintaining, expanding, and contracting the organization", in Zedeck, S.K.S., Aguinis, H., Cascio, W.F., Gelfand, M.J., Leung, K.P. and Zhou, J. (Eds), Motivating Employees, American Psychological Association, Washington, DC, pp. 65-135.

Donaldson, C. (2019), "Intentions resurrected: a systematic review of entrepreneurial intention research from 2014 to 2018 and future research agenda", The International Entrepreneurship and Management Journal, Vol. 15 No. 3, pp. 953-975.

Duffy, J.A., Fox, S., Punnett, B.J., Gregory, A., Lituchy, T., Monserrat, S.I., Olivas-Lujan, M.R., Santos, N.M.B.F. and Miller, J. (2006), "Successful women of the Americas: the same or different?", Management Research News, Vol. 29 No. 9, pp. 552-572.

Espiritu-Olmos, R. and Sastre-Castillo, M.A. (2015), "Personality traits versus work values: comparing psychological theories on entrepreneurial intention", Journal of Business Research, Vol. 68 No. 7 , pp. 1595-1598.

Farrington, S., Gray, B. and Sharp, G. (2011), "Perceptions of an entrepreneurial career: do small business owners and university students concur?", Management Dynamics: Journal of the Southern African Institute for Management Scientists, Vol. 20 No. 2, pp. 1-17.

Fayolle, A. and Liñán, F. (2014), "The future of research on entrepreneurial intentions", Journal of Business Research, Vol. 67 No. 5, pp. 663-666.

Fayolle, A. and Liñán, F. and Moriano, J.A. (2014), "Beyond entrepreneurial intentions: values and motivations in entrepreneurship", The International Entrepreneurship and Management Journal, Vol. 10 No. 4, pp. 679-689.

Feather, N.T. (1980), Values in Adolescence, Adelson, J. (Ed.), Wiley, New York.

Feather, N.T. (1995), "Values, valences, and choice: the influences of values on the perceived attractiveness and choice of alternatives", Journal of Personality and Social Psychology, Vol. 68 No. 6, pp. 1135-1151. 
IJEBR

27,1

Fernandes, C., Ferreira, J.J., Raposo, M., Sanchez, J. and Hernandez-Sanchez, B. (2018), "Determinants of entrepreneurial intentions: an international cross-border study", International Journal of Innovation Science, Vol. 10 No. 2, pp. 129-142.

Fishbein, M. and Ajzen, I. (1975), Belief, Attitude, Intention, and Behaviour: An Introduction to Theory and Research, Addison-Wesley Publishing Company, Reading, MA.

Galanakis, K. and Giourka, P. (2017), "Entrepreneurial path: decoupling the complexity of entrepreneurial process", International Journal of Entrepreneurial Behaviour and Research, Vol. 23 No. 2, pp. 317-335.

Gecas, V. and Burke, P.J. (1995), "Self and identity", in Karen, J.S.H., Cook, G. and Fine, A. (Eds), Sociological Perspectives on Social Psychology, Allyn and Bacon, Boston, pp. 41-67.

Geldhof, G.J., Malin, H., Johnson, S.K., Porter, T., Bronk, K.C., Weiner, M.B. and Colby, A. (2014), "Entrepreneurship in young adults: initial findings from the young entrepreneurs study", Journal of Applied Developmental Psychology, Vol. 35 No. 5, pp. 410-421.

Goldberg, L.R. (1993), “The structure of phenotypic personality traits”, American Psychologist, Vol. 48 No. 1, pp. 26-34.

Gorgievski, M.J., Ascalon, M.E. and Stephan, U. (2011), "Small business owners' success criteria, a values approach to personal differences", Journal of Small Business Management, Vol. 49 No. 2, pp. 207-232.

Gorgievski, M.J., Stephan, U., Laguna, M. and Moriano, J.A. (2018), "Predicting entrepreneurial career intentions: values and the theory of planned behavior", Journal of Career Assessment, Vol. 26 No. 3, pp. 457-475.

Grant, A.M. and Gino, F. (2010), "A little thanks goes a long way: explaining why gratitude expressions motivate prosocial behavior”, Journal of Personality and Social Psychology, Vol. 98 No 6, pp. 946-955.

Hirschi, A. and Fischer, S. (2013), "Work values as predictors of entrepreneurial career intentions", Career Development International, Vol. 18 No. 3, pp. 216-231.

Hitlin, S. (2003), "Values as the core of personal identity: drawing links between two theories of self", Social Psychology Quarterly, Vol. 66 No. 2, pp. 118-137.

Holland, J.L. (1997), Making Vocational Choices: A Theory of Vocational Personalities and Work Environments, 3rd ed., Psychological Assessment Resources, Odessa, FL.

Holland, D.V. and Shepherd, D.A. (2013), 'Deciding to persist: adversity, values, and entrepreneurs' decision policies", Entrepreneurship Theory and Practice, Vol. 37 No. 2, pp. 331-358.

Homer, P.M. and Kahle, L.R. (1988), "A structural equation test of the value-attitude-behavior hierarchy", Journal of Personality and Social Psychology, Vol. 54 No. 4, pp. 638-646.

Hueso, J.A., Jaén, I., Liñán, F. and Basuki, W. (2020), "The influence of collectivistic personal values on the formation of entrepreneurial intentions", International Small Business Journal, Vol. 38 No. 5, pp. 449-473.

Jaén, I. and Liñán, F. (2013), "Work values in a changing economic environment: the role of entrepreneurial capital”, International Journal of Manpower, Vol. 34 No. 8, pp. 939-960.

Jones, M.V., Coviello, N. and Tang, Y.K. (2011), "International entrepreneurship research (1989-2009): a domain ontology and thematic analysis", Journal of Business Venturing, Vol. 26 No. 4, pp. 632-659.

Kautonen, T., Van Gelderen, M. and Tornikoski, E.T. (2013), "Predicting entrepreneurial behaviour: a test of the theory of planned behaviour", Applied Economics, Vol. 45 No. 6, pp. 697-707.

Kautonen, T., Gelderen, M. and Fink, M. (2015), "Robustness of the theory of planned behavior in predicting entrepreneurial intentions and actions", Entrepreneurship Theory and Practice, Vol. 39 No. 3, pp. 655-674.

Kluckhohn, C. (1951), "Values and value-orientations in the theory of action: an exploration in definition and classification", in Parsons, T. and Shils, E. (Eds), Toward a General Theory of Action, Harvard University Press, Cambridge. 
Krueger, N.F. (2007), "What lies beneath? The experiential essence of entrepreneurial thinking", Entrepreneurship Theory and Practice, Vol. 31 No. 1, pp. 123-138.

Krueger, N.F. and Carsrud, A.L. (1993), "Entrepreneurial intentions: applying the theory of planned behaviour", Entrepreneurship and Regional Development, Vol. 5 No. 4, pp. 315-330.

Kruse, P., Wach, D., Costa, S. and Moriano, J.A. (2019), "Values matter, don't they?-combining theory of planned behavior and personal values as predictors of social entrepreneurial intention", Journal of Social Entrepreneurship, Vol. 10 No. 1, pp. 55-83.

Kunttu, A. and Puumalainen, K. and Fellnhofer, K. (2017), "Socially-oriented entrepreneurial goals and intentions: the role of values and knowledge", Journal for International Business and Entrepreneurship Development, Vol. 10 No. 4, pp. 337-361.

Lechner, C.M., Sortheix, F.M., Obschonka, M. and Salmela-Aro, K. (2018), "What drives future business leaders? How work values and gender shape young adults' entrepreneurial and leadership aspirations", Journal of Vocational Behavior, Vol. 107, pp. 57-70.

Liñán, F. and Rodríguez-Cohard, J.C. (2015), "Assessing the stability of graduates' entrepreneurial intention and exploring its predictive capacity", Academia Revista Latinoamericana de Administración, Vol. 28 No. 1, pp. 77-98.

Liñán, F. and Fayolle, A. (2015), "A systematic literature review on entrepreneurial intentions: citation, thematic analyses, and research agenda", The International Entrepreneurship and Management Journal, Vol. 11 No. 4, pp. 907-933.

Liñán, F. and Moriano, J.A. and Jaén, I. (2016), "Individualism and entrepreneurship: does the pattern depend on the social context?", International Small Business Journal, Vol. 34 No. 6, pp. 760-776.

Lyons, S.T., Higgins, C.A. and Duxbury, L. (2010), "Work values: development of a new threedimensional structure based on confirmatory smallest space analysis", Journal of Organizational Behavior, Vol. 31 No. 7, pp. 969-1002.

Maio, G.R., Olson, J.M., Allen, L. and Bernard, M.M. (2001), "Addressing discrepancies between values and behavior: the motivating effect of reasons", Journal of Experimental Social Psychology, Vol. 37 No. 2, pp. 104-117.

Mair, J. and Noboa, E. (2006), "Social entrepreneurship: how intentions to create a social venture are formed", in Mair, J., Robinson, J. and Hockerts, K. (Eds), Social Entrepreneurship, Palgrave Macmillan, London.

Maslow, A.H. (1959), New Knowledge in Human Values, Harper, New York, NY.

McCrae, R.R. and Costa, P.T.Jr. (2008), "The five-factor theory of personality", in John, O.P., Robins, R.W. and Pervin, L.A. (Eds), Handbook of Personality: Theory and Research, The Guilford Press, New York, pp. 159-181.

Miller, M.J., Woehr, D.J. and Hudspeth, N. (2002), "The meaning and measurement of work ethic: construction and initial validation of a multidimensional inventory", Journal of Vocational Behavior, Vol. 60 No. 3, pp. 451-489.

Moon, B. (1995), "Paradigms in migration research: exploring' moorings' as a schema”, Progress in Human Geography, Vol. 19 No. 4, pp. 504-524.

Morales, C., Holtschlag, C., Masuda, A.D. and Marquina, P. (2019), "In which cultural contexts do individual values explain entrepreneurship? An integrative values framework using Schwartz's theories”, International Small Business Journal, Vol. 37 No. 3, pp. 241-267.

Muhammad, N., Robinson, D. and Nisar, M. (2019), "The influence of Muslim marriages on entrepreneurial intentions of women entrepreneurs", International Journal of Entrepreneurial Behavior and Research, Vol. 25 No. 7, pp. 1389-1409.

Mulrow, C.D. (1994), "Systematic reviews: rationale for systematic reviews", British Medical Journal, Vol. 309 No. 6954, pp. 597-599. 
IJEBR

27,1

Myyry, L. and Juujärvi, S. and Pesso, K. (2013), "Change in values and moral reasoning during higher education”, European Journal of Developmental Psychology, Vol. 10 No. 2, pp. 269-284.

Nga, J.K.H. and Shamuganathan, G. (2010), "The influence of personality traits and demographic factors on social entrepreneurship start up intentions", Journal of Business Ethics, Vol. 95 No. 2, pp. 259-282.

Olver, J.M. and Mooradian, T.A. (2003), "Personality traits and personal values: a conceptual and empirical integration", Personality and Individual Differences, Vol. 35 No. 1, pp. 109-125.

Overton, W.F. (2010), "Life-span development: concepts and issues", in Overton, W.R. and Lerner, R.M. (Eds), Cognition, Biology, and Methods Across the Life Span. Handbook of Lifespan Development, Wiley, Hoboken, NJ.

Overton, W.F. (2013), "A new paradigm for developmental science: relationism and relationaldevelopmental systems", Applied Developmental Science, Vol. 17 No. 2, pp. 94-107.

Palmatier, R.W., Houston, M.B. and Hulland, J. (2018), "Review articles: purpose, process, and structure", Journal of the Academy of Marketing Science, Vol. 46 No. 1, pp. 1-5.

Pepper, S.C. (1958), The Sources of Value, University of California Press, London.

Pfeifer, S., Šarlija, N. and ZekićSušac, M. (2016), "Shaping the entrepreneurial mindset: entrepreneurial intentions of business students in Croatia”, Journal of Small Business Management, Vol. 54 No. 1, pp. 102-117.

Pilková, A., Holienka, M. and Jančovičová, Z. (2017), "Investigating youth entrepreneurial intentions' drivers in Visegrad countries", Acta Universitatis Agriculturae et Silviculturae Mendelianae Brunensis, Vol. 65 No. 6, pp. 2055-2065.

Pittaway, L., Holt, R. and Broad, J. (2014), "Synthesising knowledge in entrepreneurship research-the role of systematic literature reviews", in Chell, E. and Karataş-Özkan, M. (Eds), Handbook of Research on Small Business and Entrepreneurship, Edward Elgar Publishing, Cheltenham.

Racko, G., Strauss, K. and Burchell, B. (2017), "Economics education and value change: the role of program-normative homogeneity and peer influence", The Academy of Management Learning and Education, Vol. 16 No. 3, pp. 373-392.

Rauch, A. (2020), "Opportunities and threats in reviewing entrepreneurship theory and practice", entrepreneurship theory and practice", Entrepreneurship Theory and Practice, Vol. 44 No. 5, pp. 847-860.

Reynolds, T.J. and Gutman, J. (1988), "Laddering theory, method, analysis, and interpretation”, Journal of Advertising Research, Vol. 28 No. 1, pp. 11-31.

Rohan, M.J. (2000), "A rose by any name? The values construct", Personality and Social Psychology Review, Vol. 4 No. 3, pp. 255-277.

Rokeach, M. (1973), The Nature of Human Values, Free Press, New York, NY.

Ryan, R.M. and Deci, E.L. (2000), "Self-determination theory and the facilitation of intrinsic motivation, social development, and well-being", American Psychologist, Vol. 55 No. 1, pp. 68-78.

Sastre-Castillo, M.A., Peris-Ortiz, M. and Danvila-Del Valle, I. (2015), "What is different about the profile of the social entrepreneur?", Nonprofit Management and Leadership, Vol. 25 No. 4, pp. 349-369.

Schlaegel, C. and Koenig, M. (2014), "Determinants of entrepreneurial intent: a meta-analytic test and integration of competing models", Entrepreneurship Theory and Practice, Vol. 38 No. 2, pp. 291-332. 
Schmidt, P. and Tatarko, A.N. (2016), "Entrepreneurial intention and values: results from a Russian population survey", Psychology. Journal of the Higher School of Economics, Vol. 13 No. 2, pp. 240-255.

Schwartz, S.H. (1992), "Universals in the content and structure of values: theoretical advances and empirical tests in 20 countries", Advances in Experimental Social Psychology, Vol. 25 No. 1, pp. 1-65.

Schwartz, S.H. and Bilsky, W. (1987), "Toward a universal psychological structure of human values", Journal of Personality and Social Psychology, Vol. 53 No. 3, pp. 550-562.

Shepherd, D.A. (2015), "Party on! A call for entrepreneurship research that is more interactive, activity based, cognitively hot, compassionate, and prosocial", Journal of Business Venturing, Vol. 30 No. 4, pp. 489-507.

Shepherd, D.A., Patzelt, H. and Baron, R.A. (2013), "I care about nature, but. . .': disengaging values in assessing opportunities that cause harm", Academy of Management Journal, Vol. 56 No. 5, pp. 1251-1273.

Sihombing, S.O. (2018), "Empirical results of predicting the relationship between value, attitude, and intention to quit as an entrepreneur", Journal of Southeast Asian Research, Vol. 2018, pp. 1-13.

Super, D.E. (1980), “A life-span, life-space approach to career development”, Journal of Vocational Behavior, Vol. 16 No. 3, pp. 282-298.

Tipu, S.A.A. and Ryan, J.C. (2016), "Predicting entrepreneurial intentions from work values: implications for stimulating entrepreneurship in UAE national youth", Management Decision, Vol. 54 No. 3, pp. 610-629.

Tranfield, D., Denyer, D. and Smart, P. (2003), "Towards a methodology for developing evidenceinformed management knowledge by means of systematic review", British Journal of Management, Vol. 14 No. 3, pp. 207-222.

Twenge, J.M., Campbell, S.M., Hoffman, B.J. and Lance, C.E. (2010), "Generational differences in work values: leisure and extrinsic values increasing, social and intrinsic values decreasing", Journal of Management, Vol. 36 No. 5, pp. 1117-1142.

van Gelderen, M., Kautonen, T., Wincent, J. and Biniari, M. (2018), "Implementation intentions in the entrepreneurial process: concept, empirical findings, and research agenda”, Small Business Economics, Vol. 51 No. 4, pp. 923-941.

Veroff, J. and Smith, D.A. (1985), "Motives and values over the adult years", Advances in Motivation and Achievement, Vol. 4, pp. 1-53.

Watchravesringkan, K., Hodges, N.N., Yurchisin, J., Hegland, J., Karpova, E., Marcketti, S. and Yan, R. (2013), "Modeling entrepreneurial career intentions among undergraduates: an examination of the moderating role of entrepreneurial knowledge and skills", Family and Consumer Sciences Research Journal, Vol. 41 No. 3, pp. 325-342.

Wu, W., Wang, H., Zheng, C. and Wu, Y.J. (2019), "Effect of narcissism, psychopathy, and machiavellianism on entrepreneurial intention - the mediating of entrepreneurial self-efficacy", Frontiers in Psychology, Vol. 10, p. 360.

Yang, K.-P., Hsiung, H.-H. and Chiu, Y.-J. (2015), "The comfort zone of the value circumplex for entrepreneurship: a structural analysis", Career Development International, Vol. 20 No. 6, pp. 663-683.

Ye, Q., Zhou, R., Anwar, M.A. and Siddiquei, A.N. and Asmi, F. (2020), "Entrepreneurs and environmental sustainability in the digital era: regional and institutional perspectives", International Journal of Environmental Research and Public Health, Vol. 17 No. 4, p. 1355.

Zahra, S.A., Wright, M. and Abdelgawad, S.G. (2014), "Contextualization and the advancement of entrepreneurship research", International Small Business Journal, Vol. 32 No. 5, pp. 479-500. 


\section{IJEBR \\ Appendix \\ 27,1}

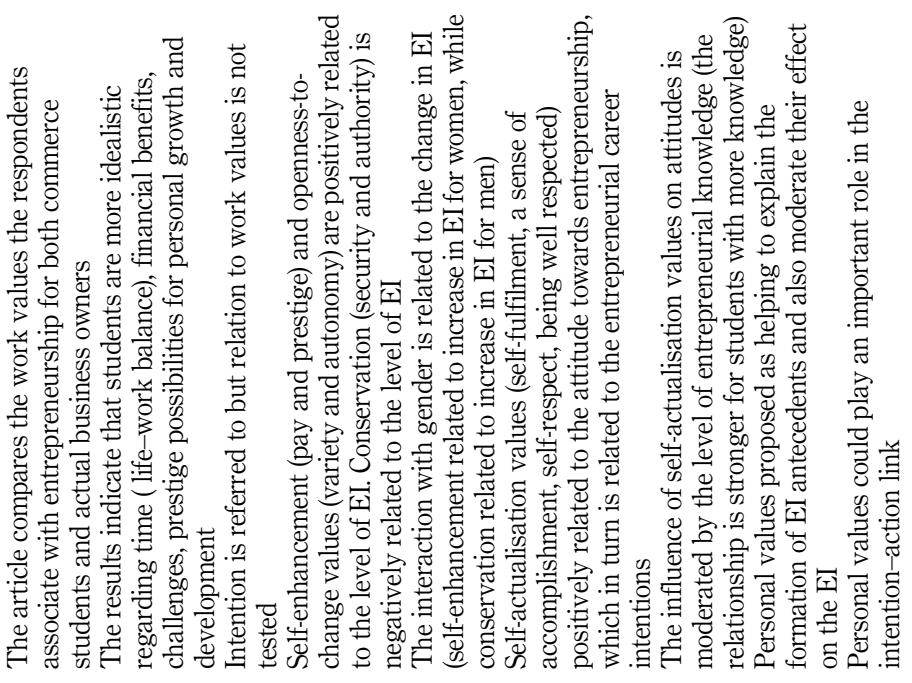

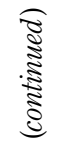

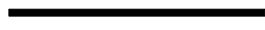

Table A1.

Papers included in the systematic literature
㟒

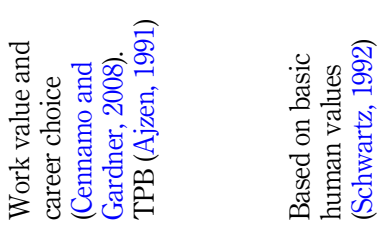

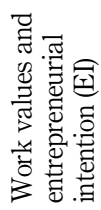

言苛

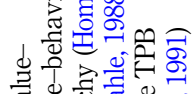

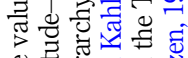

总总焉恶
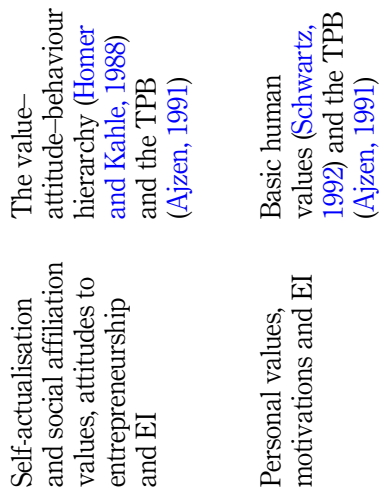

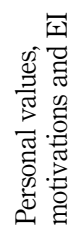

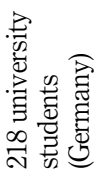

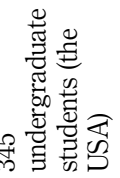

范

范

若

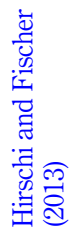

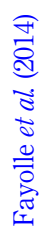




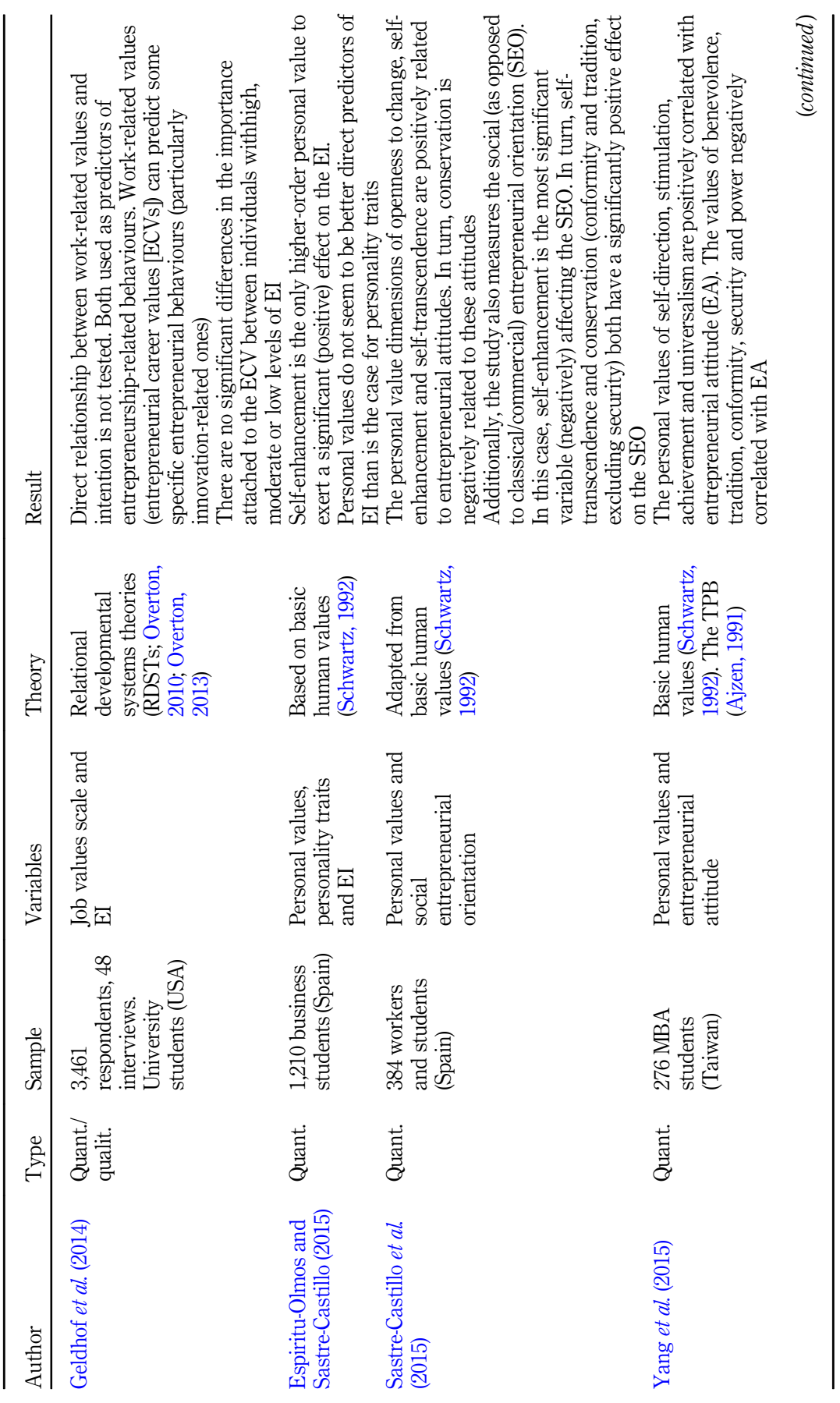

Personal

values to entrepreneurial intention

225

Table A1. 


\section{IJEBR}

27,1

Table A1. 


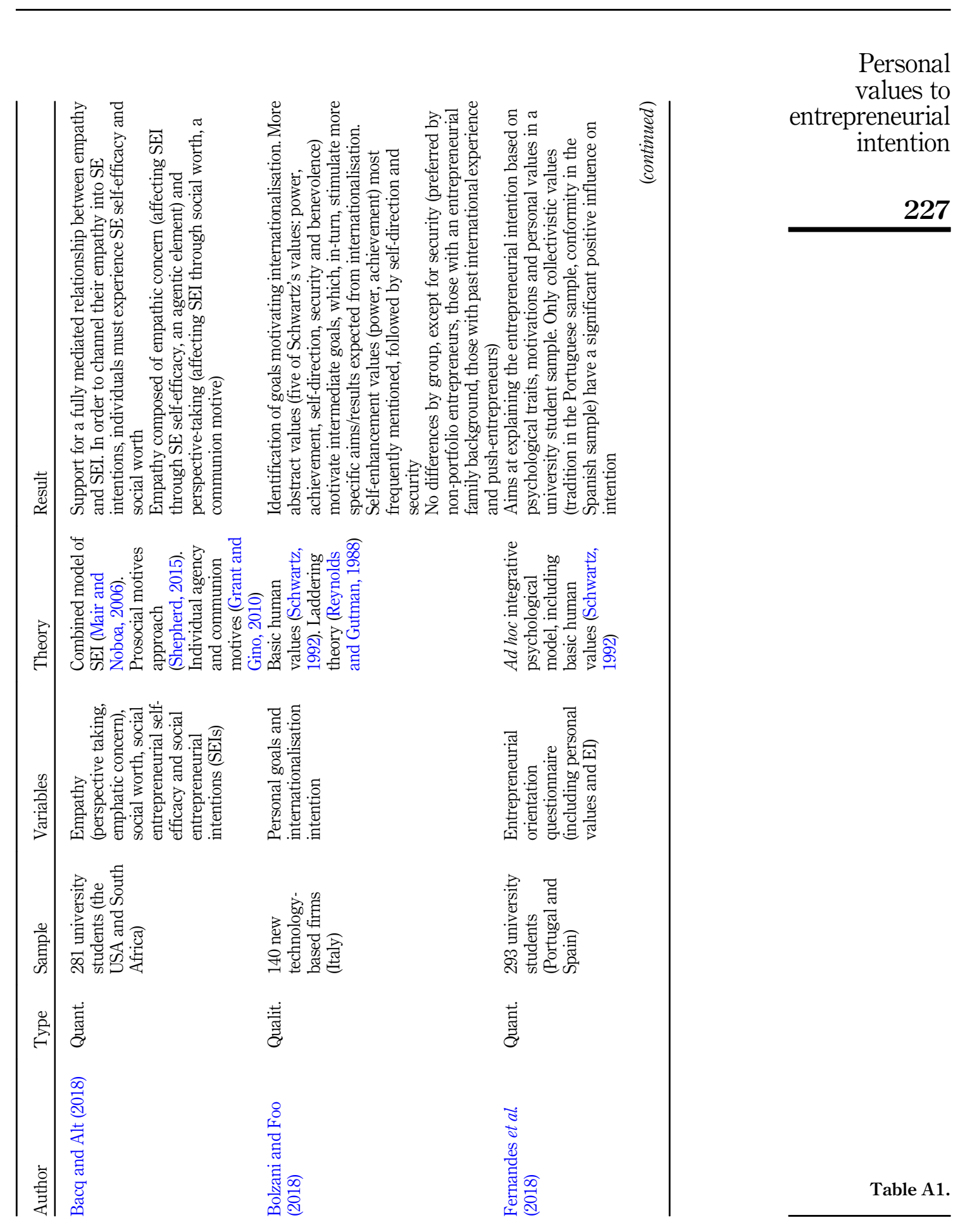




\section{IJEBR \\ 27,1}

228

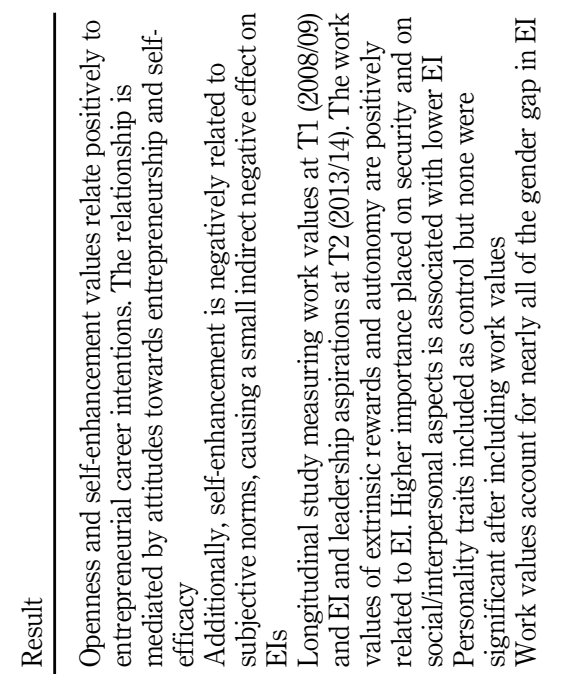

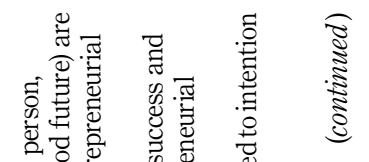

Table A1.

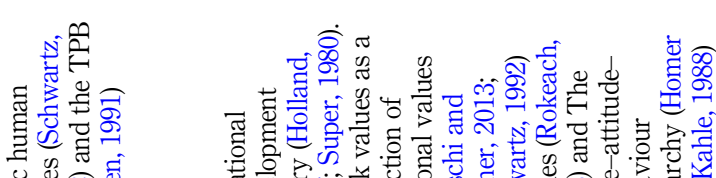

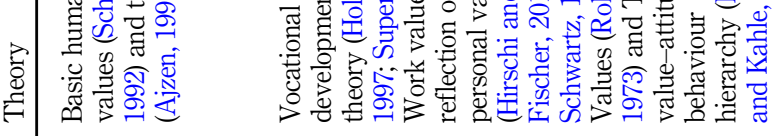

:

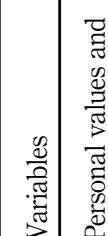

焉

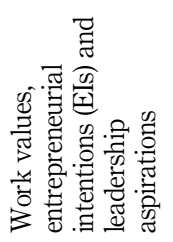

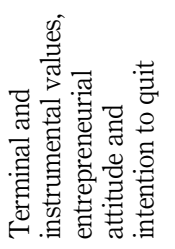

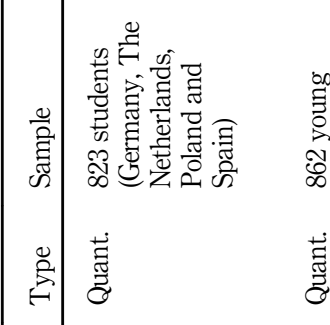

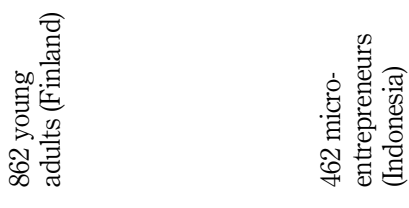

范

范

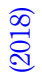

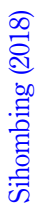

胥

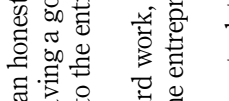

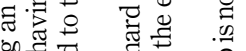

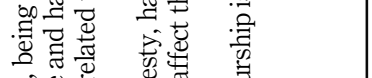

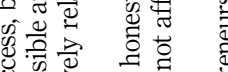

के

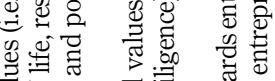

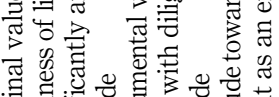

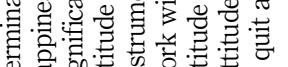

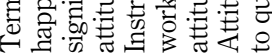




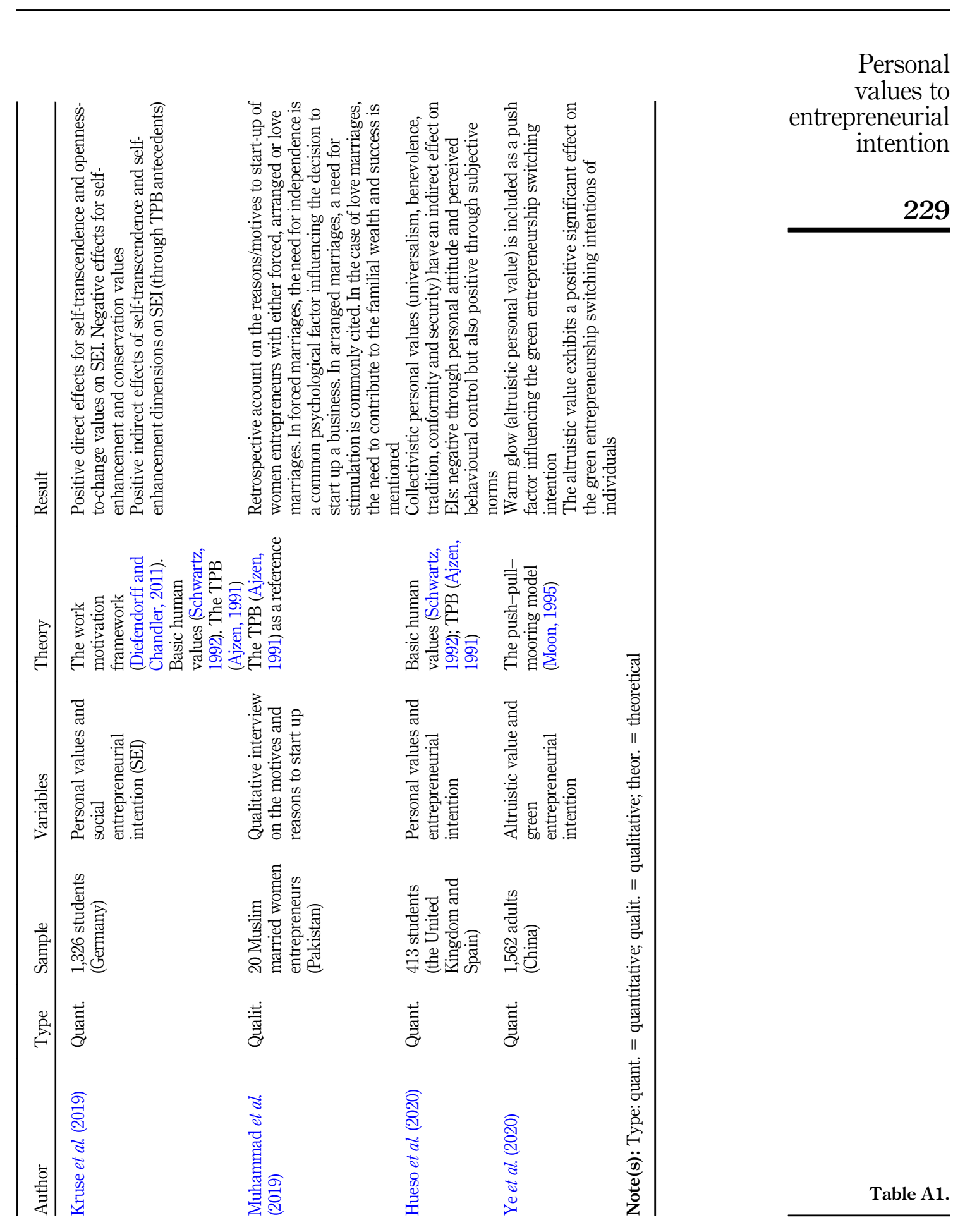


IJEBR

27,1

\begin{abstract}
About the authors
Juan Alberto Hueso is a PhD-granted student at the University of Seville (Spain). He got his bachelor's degree in economics. His research interests are related to personal values in the entrepreneurs' identity formation and the process of entrepreneurial intention. Juan Alberto has participated in projects sponsored by the Spanish National Government (ELITE) and the Organisation for Economic Co-operation and Development (OECD). He is actively participating in the European University Network on Entrepreneurship (ESU).

Inmaculada Jaén holds a PhD degree in economics from the University of Seville. She is an assistant professor of economics in the Department of Applied Economics, University of Seville, and a member of the research group "SMEs and Economic Development". She has participated in several research projects funded by the regional and national administrations as well as the OECD. Dr. Jaén is a part of the ELITE project (Ref.: ECO2016-75655-P) financed by the Ministry of Economy and Competitiveness in Spain. She has published a number of contributions in academic journals and edited books.

Francisco Liñán is a professor in entrepreneurship and innovation at Anglia Ruskin University (UK) as well as an associate professor at the University of Seville (Spain). His research interests include entrepreneurship, the entrepreneurial process and entrepreneurship education. His work has been published in journals such as International Small Business Journal, Entrepreneurship Theory and Practice, Entrepreneurship and Regional Development and Small Business Economics. He has participated in projects funded by the Spanish National Government, the EU and the OECD. He is a research editor at Entrepreneurship Education \& Pedagogy and an editorial board member at Entrepreneurship Theory and Practice and International Entrepreneurship and Management Journal. Francisco Liñán is the corresponding author and can be contacted at: flinan@us.es
\end{abstract}

For instructions on how to order reprints of this article, please visit our website:

www.emeraldgrouppublishing.com/licensing/reprints.htm

Or contact us for further details: permissions@emeraldinsight.com 